\title{
Two species of Mastigodiaptomus (Copepoda: Diaptomidae), hosts of the epibiotic ciliate Trichodina diaptomi (Peritricha) in North America
}

\author{
Marcelo SILVA-BRIANO, Eduardo SUÁREZ-MORALES ${ }^{1}{ }^{*}$, Araceli ADABACHE ORTIZ and \\ Montserrat REYES-FLORES \\ Universidad Autónoma de Aguascalientes, Centro de Ciencias Básicas, Departamento de Biología, Av. Universidad No. 490, Ciudad \\ Universitaria, C. P. 20100 Aguascalientes, Ags. Mexico \\ ${ }^{1)}$ El Colegio de la Frontera Sur (ECOSUR), Unidad Chetumal, A.P. 424, Chetumal, Quintana Roo 77014, Mexico \\ *e-mail corresponding author: esuarez@ecosur.mx
}

\begin{abstract}
The peritrich epibiotic ciliate Trichodina diaptomi Basson and Van As, 1991 was recorded on the body surface of two Neotropical species of the calanoid copepod genus Mastigodiaptomus in north-central Mexico. Specimens infested with the ciliate were collected from a pond near a large eutrophic reservoir. This ciliate was identified as T. diaptomi by its body size, the morphometry or shape of the taxonomically relevant structures such as the adhesive disc, macronucleus, and denticles or the modal number of radial pins, rays, and denticles. The Mexican specimens have a higher modal number of denticles with respect to other known populations of T. diaptomi. Ciliates were observed crawling freely over the copepod cephalothorax and attached at times, leaving a mark on the cuticle but causing no evident physical harm to the copepod. Our observations arise some doubt concerning the presumedly parasitic association of this species with copepods. This widespread species, currently known as a symbiont of 10 species of diaptomid copepods, was reported recently for the first time in the Americas, from Brazil. This is the second illustrated record of this epibiotic ciliate in the continent and the first in North America.
\end{abstract}

Key words: freshwater zooplankton, copepods, associate protozoans, trichodinids

\section{INTRODUCTION}

The speciose ciliate genus Trichodina Ehrenberg, 1830 is represented by more than 200 nominal species of epibionts or ectoparasites (Xu \& Song 2008). Trichodinids live associated to different kinds of aquatic invertebrates and vertebrates, including hydrozoans, crustaceans, mollusks, fishes, and amphibians (Fernández-Leborans \& Tato-Porto 2000; Asmat 2005; Xu \& Song 2008). They have been known to feed on bacteria and sometimes skin cells of the host (Foissner et al. 1999). As parasites they appear to have a preference to a variety of fishes, even in cultured species (Mitra \& Bandyopadhyay 2005; Martins et al. 2010). Infestations of gills and skin have been proved to negatively affect the ecological performance of the hosts (Xu \& Burns 1991). Trichodina diaptomi Basson \& Van As, 1991 is a species originally described from South Africa where it was found to be associated to freshwater calanoid copepods (Basson \& Van As 1991). Previous records of other trichodinids from freshwater copepod hosts were assigned to this species. It is currently deemed as a highly variable species with a wide distributional range that includes Europe, Asia, and Australia (Green \& Shiel 2000). This epibiotic ciliate had not been recorded in the Americas until it was reported in Brazil (Da Silva et al. 2009) on the diaptomid copepod Notodiaptomus deitersi (Poppe, 1891). Trichodina diaptomi has not been hitherto recorded from North
America. During a survey of the freshwater zooplankton of the north-central region of Mexico, several diaptomid copepods were found to have ciliate protozoans moving on their body surface. These ciliates were closely examined to identify them to the species level using SEM analysis. We report the results of this analysis together with comments on the ciliate $T$. diaptomi.

\section{MATERIALS AND METHODS}

During a survey aimed to assess the diversity and distribution of the freshwater zooplankton of the northcentral region of Mexico, zooplankton samples were collected from different habitats. A sample recently collected from the area of the Abelardo Rodríguez Dam $\left(21^{\circ} 54^{\prime} 32.84 " \mathrm{~N}\right.$; $\left.102^{\circ} 25^{\prime} 19.62^{\prime \prime W}\right)$ in September 11, 2010 contained many individuals of diaptomid copepods; some of them were infested with ciliates. Some of these specimens, adult males and females of Mastigodiaptomus albuquerquensis (Herrick, 1895) and $M$. montezumae (Brehm, 1955), were fixed with a $4 \%$ formalin solution. Other specimens were kept live to allow observations on the activity of the ciliates on the body surface of the copepods; such individuals were then sorted and transferred to $70 \%$ ethanol for long-term preservation. The taxonomic analysis of the ciliate protozoans involved a process of slow narcotization of live specimens using a saturated solution of menthol and adding drops of a $4 \%$ formalin solution. Once fixed, specimens were mounted in slides with glycerine as a 
mounting medium and DePeX GURR as sealant. Some copepod specimens still carrying the ciliates were processed for SEM analysis using a JEOL LV5900 microscope. In order to identify the epibiont ciliates, measurements of different structures of their bodies were taken following Green \& Shiel (2000). Specimens were deposited in the collection of Zooplankton at El Colegio de la Frontera Sur (ECOSUR, ECO-CHZ), Chetumal, Mexico and in the collection of the first author in the University of Aguascalientes.

\section{RESULTS AND DISCUSSION}

Hosts and locality: Mastigodiaptomus albuquerquensis (Herrick, 1895) and M. montezumae (Brehm, 1955) from a pond in the area adjacent to the Abelardo Rodríguez Dam (215' $32.84 " N$; $\left.102^{\circ} 25^{\prime} 19.62 " W\right)$, state of Aguascalientes, north-central Mexico (ECOCHZ-07500).

Infestation site. Prosome of both diaptomid species.

Taxonomy and morphology. The taxonomic analysis and SEM observations of these Mexican ciliates allowed the identification of $T$. diaptomi Basson \& Van As, 1991. The specimens observed are medium sized trichodinids with flattened, saucer-like body, "C"shaped nucleus, and blades of denticles broadly sickleshaped with its distal surface weakly curved. Morphology of denticles (Fig. 1) as follows: posterior margin forming semi-lunar sinus with deepest point at same level as apex. Apex usually not touching $\mathrm{y}+1$ axis. Section connecting blade and central part delicate or robust. As usual in T. diaptomi, our specimens have the central part curve clearly extending more than halfway to $y-1$ axis. Section above $\mathrm{x}$ axis roughly triangular, section below x axis parallel for half the distance; in the Mexican specimens the parallel section is less than half the distance. Ray with a rounded sharp point, bent towards $\mathrm{y}+1$ axis and in some cases parallel to this axis (see Basson \& Van As 1999; Green \& Shiel 2000). Ratio of section below and above $\mathrm{x}$ axis approximately 1 . Morphological and meristic data of the body of the trichodinid specimens from Mexico are given in table 1, including a comparison of additional characters and numerical ranges among different populations of $T$. diaptomi.

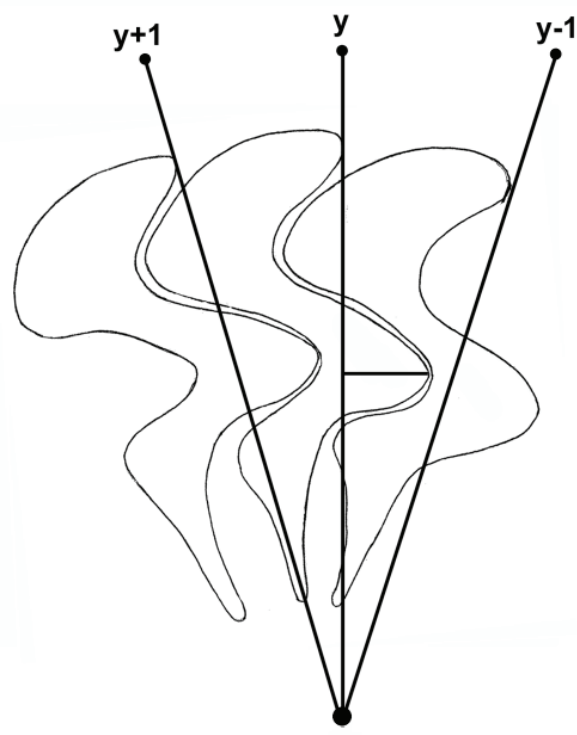

Fig. 1. Diagramatic illustration of the denticles of a specimen of Trichodina diaptomi associated to diaptomid copepods from north-central Mexico.

The work by Green \& Shiel (2000) was the main source of numerical data for comparison because a complete set of measurements was not available from Da Silva et al. (2009) for Brazilian specimens.

Biometrical and morphological data of the Mexican specimens largely agree with the character ranges of the species summarized by Basson \& Van As (1991) and Green \& Shiel (2000). From the comparative data presented in table 1 , the averaged $(n=20)$ values for the Mexican specimens are compared with those known for this species (in brackets), as follows: mean body diameter: $40.41 \mu \mathrm{m}$ (43.6), mean adhesive disc diameter: $34.54 \mu \mathrm{m}$ (35.9), mean denticle ring diameter: 19.8 $\mu \mathrm{m}$ (20.1), modal number of denticles: 22 (17), modal number of radial pins per denticle: 9 (9). Also, a "C2 shaped macronucleus (Fig. 2D), and the distinctive shape and dimensions of denticles, indicate that the species found also infesting the examined copepods from Mexico is T. diaptomi Basson \& Van As (1991) (Figs. 2C, 3A-D). Overall, our specimens from Mexico fall well into the known biometrical and meristic ranges of

Tab. 1. Comparison of the biometrical data of the specimens of Trichodina diaptomi from Mexico with those from South Africa and Australia + South Africa, the latter data set deemed as representative of the entire known species range. Values provided are ranges, followed by the mean and standard deviation, except in instances marked $*$ where the values in parentheses are modal values. All measurements are in micrometers. Measurements of Mexican specimens based on $n=20$.

\begin{tabular}{lccc}
\hline Character & T. diaptomi from South Africa & T. diaptomi range (Australia+S.Africa) & T. diaptomi from Mexico \\
\hline Body diameter & $33.8-48.7(41.5 \pm 4.4)$ & $33-49.6$ & $38.1-44.6(40.4)$ \\
Adhesive disc diameter & $27.9-39.9(33.8 \pm 3.5)$ & $27-42.6$ & $29.3-39.8(34.5)$ \\
Border membrane width & $2.6-5.4(4.0 \pm 0.7)$ & $1.8-5.4$ & $2.6-3.8(2.98)$ \\
Denticle ring diameter & $14.8-22.6(19.6 \pm 2.3)$ & $14.8-39.1$ & $18.1-22.8(19.8)$ \\
Denticle number* & $15-20$ & $15-20$ & $20-24(22)$ \\
Radial pins/denticle* & $7-11(9)$ & $5-11(9)$ & $8-11(9)$ \\
Denticle length & $4.8-7.7(6.2 \pm 0.8)$ & $4.4-7.7$ & $5.7-6.9(6.28)$ \\
Ray length & $2.8-6.1(4.4 \pm 0.8)$ & $2.8-6.4$ & $4.8-6.2(5.72)$ \\
Macronucleus & C- shaped & C-shaped & C-shaped \\
\hline
\end{tabular}



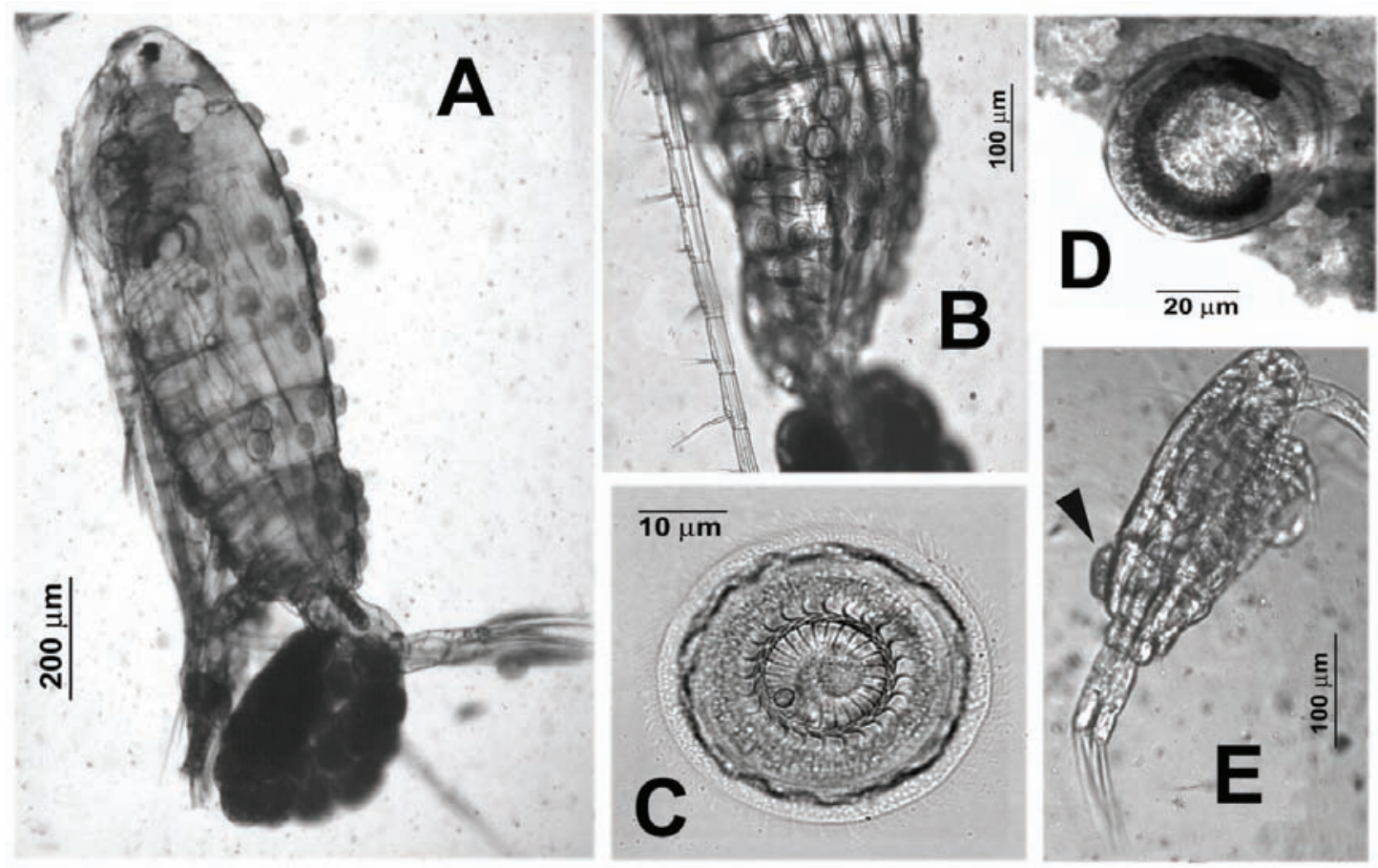

Fig. 2. Trichodina diaptomi from north-central Mexico. A) heavy infestation of T. diaptomi on adult M. albuquerquensis; B) infestation on cephalothorax of the copepod $M$. albuquerquensis, lateral view; C) adhesive disc showing denticles and rays; D) specimen showing "C2-shaped macronucleus; E) copepodite III stage of M. albuquerquensis already infested by T. diaptomi.

the species (see Tab. 1); however, there are morphological variations of the Mexican specimens that should be remarked.

In the species pattern, the denticle apex usually does not touch the $\mathrm{y}+1$ axis; however, in all Mexican specimens the apex touches and even goes beyond $\mathrm{y}+1$ axis. This kind of variation has been reported also by Green \& Shiel (2000) in some individuals of T. diaptomi from Australia. Also, as described by the same authors, the section connecting the blade and the central part is usually delicate but in some populations it can be relatively robust, as in our specimens. In T. diaptomi, the section below the $\mathrm{x}$ axis is usually parallel for half the distance; however, in the Mexican specimens the parallel section is less than half the distance, a variation observed in other populations as well (Basson \& Van As 1991). Furthermore, there are some variations in the size of the central ring, the number of denticles, and the shape of the denticles. Denticle number and number of radial pins per denticle are regarded as being particularly important taxonomically and relatively stable within a species, varying by only 3-4 denticles and 2-4 radial pins per denticle (Lom 1958). The reported modal number of denticles of T. diaptomi is 17 for the Australian populations (Green \& Shiel 2000), 18 in the South African, 19 in the Brazilian, and 22 in the surveyed Mexican population. The modal value of pins per denticle is 9 in all the compared populations; also, it is recognized that the shape of the denticles is highly variable in this species (Basson \& Van As 1991; Green \& Shiel 2000). Overall, the main characters evaluated in the
Mexican population fit the species range. Consequently, we conclude that the Mexican population belongs to $T$. diaptomi; the morphological differences between it with the South African and Australian populations provide evidence of ecotypic/geographical variation of the species. In agreement with the position of Green \& Shiel (2000), the differences found in the Mexican populations with respect to populations of $T$. diaptomi from other geographic areas were not considered relevant enough to suggest that they belong to a distinct taxon. Furthermore, it was presumed that the only other American population of this species, from Brazil, would have a closer morphological similitude with the Mexican specimens. Only few measurements were provided by Da Silva et al. (2009) from the Brazilian specimens $(\mathrm{n}=20)$ : mean body diameter $38.3 \mathrm{~mm}(\mathrm{SD} \pm 4.2 \mathrm{~mm})$, mean adhesive disc diameter $31.5 \mathrm{~mm}(\mathrm{SD} \pm 3.1 \mathrm{~mm})$, 8-10 radial pins per denticle, modal number of denticles 19 (range 18-20), and a "C2-shaped macronucleus. Brazilian specimens of $T$. diaptomi have a higher modal number of denticles (19) than both the Australian and South African populations (17-18); the Mexican population presents an even higher modal number (22) but the ranges overlap.

Ecology. Living specimens of $T$. diaptomi were seen moving over the entire extension of the cephalothorax of the two Neotropical diaptomid copepods occurring in the surveyed pond, M. albuquerquensis and $M$. montezumae (Figs 2A, B, 3F). The number of ciliates on the body surface of both species of Mastigodiaptomus was 

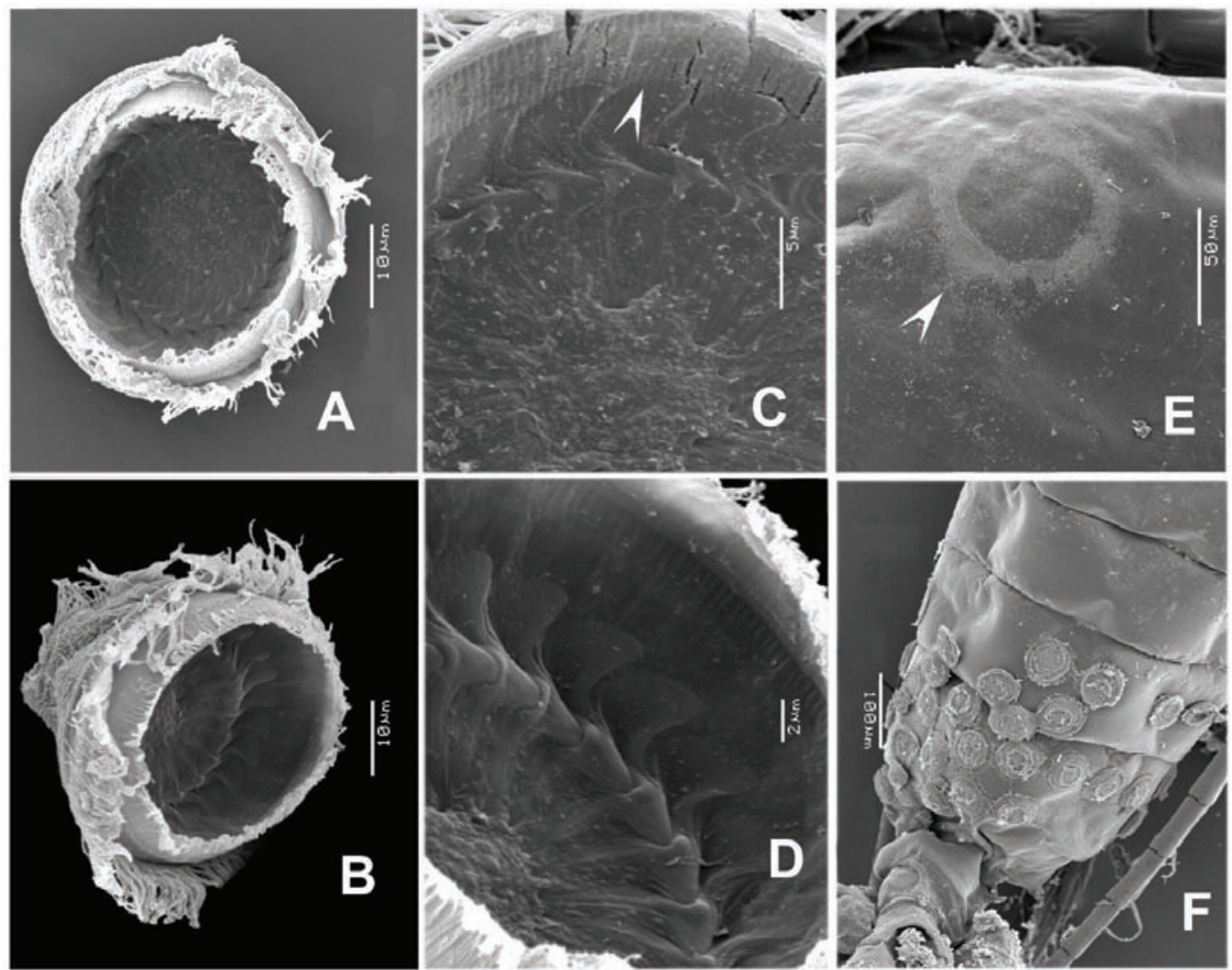

Fig. 3. Trichodina diaptomi from north-central Mexico. SEM micrographs. A) habitus, oral view showing adhesive disc; B) same, semi-lateral view; C) detail of denticles and radial pins (arrowed); D) same, another specimen; E) cuticular mark on copepod cuticular surface left by T. diaptomi; F) infestation on cephalothorax of Mastigodiaptomus montezumae.

variable, from 4 to 50, in the latter cases covering more than $60 \%$ of the cephalothorax. When present in our samples, copepodites of Mastigodiaptomus at various stages were likewise infested, including copepodites III (Fig. 2E). Green \& Shiel (2000) observed that copepodites IV were the earliest stage infested in Australian species of Boeckella; it is probable that, because of its relative size, the youngest copepods could be more affected by the presence of $T$. diaptomi. In some specimens prepared for SEM analysis we were able to locate areas of the copepod cuticular surface that have been occupied by T. diaptomi (see Fig. 3E); the ciliate left a weak mark on the surface without evidence of further damage. Many species of Trichodina have been regarded as parasitic forms (Chen 1963; Van As \& Basson 1989). In their survey on T. diaptomi, Green \& Shiel (2000) explored the body surface of infested copepods at high magnifications but were unable to determine whether there was any abrasion or damage caused by the adhesive discs of the ciliate. Based on our observations, there is still no conclusive evidence that $T$. diaptomi causes physical harm to their copepod hosts. Histopathological studies should provide additional data to reveal if there is a host inflammatory reaction at this level. Of course, the ecological and reproductive performance of the copepod could be affected by heavy infestations of the ciliate by its weight or position on the body (see Green \& Shiel 2000). Hence, our data support the idea that this species feeds on bacteria as has been observed in other trichodinids (Foissner et al. 1999) while moving on the body of its copepod host. Conditions of the sampling site, with a heavy input of organic matter appear to be quite favorable for the development of this ciliate. Its finding in Brazil, also from an eutrophic reservoir (Da Silva et al. 2009) supports this notion.

This species has a wide range of host species among eight members of the calanoid subfamily Diaptomidae, the list includes Metadiaptomus meridianus (Van Douwe, 1912) (South Africa); Sinodiaptomus sarsi (Rylov, 1923), Neodiaptomus schmackeri (Poppe \& Richard, 1892) (China); Eudiaptomus vulgaris (Schmeil, 1896) (Europe, Russia); E. zachariasi (Poppe, 1886) (Poland); Diaptomus castor (Jurine, 1820), Eudiaptomus gracilis (Sars, 1863) (Europe); Notodiaptomus deitersi (Poppe, 1891) (Brazil) (Basson \& Van As 1991; Green \& Shiel 2000; Da Silva et al. 2009). The centropagids Boeckella fluvialis Henry, 1922 and B. minuta Sars, 1896 (Australia) are also known hosts of $T$. diaptomi (Green \& Shiel 2000). We are now able to add two other diaptomid species from North America, Mastigodiaptomus albuquerquensis and M. montezumae and thus, raise the number of diaptomid hosts to 10 worldwide. These two copepod species are among the most 
widely distributed Diaptomidae in Mexico (SuárezMorales \& Reid 1998). Based on the known distribution of its hosts, it is speculated that the epibiont ciliate has the potential to spread widely not only in Mexico but in Central and North America as well. This is the second record of this species in the Americas (Da Silva et al. 2009) and the first in North America. Whether T. diaptomi has reached South and North America naturally or by human activity is still an open question.

\section{ACKNOWLEDGEMENTS}

Our gratitude to Alejandra Sofía Sánchez Ávila, student of Biology at the University of Aguascalientes, Mexico, for her help in processing the ciliate and copepod specimens for SEM analysis. The comments and suggestions by two anonymous reviewers greatly improved an earlier version of this work.

\section{REFERENCES}

Asmat, G.S.M. 2005. Trichodinid ectoparasites (Ciliophora: Trichodinidae) of fishes in India. Res. J. Agric. Biol. Sci., 1: 31-37.

Basson, L. \& J.G. Van As. 1991. Trichodinids (Ciliophora: Peritrichia) from a calanoid copepod and catfish from South Africa with notes on host specificity. Syst. Parasitol., 18: 147-158.

Chen, C-L. 1963. Studies on ectoparasitic trichodinids from freshwater fish, tadpoles and crustaceans in China. Acta Hydrobiol. Sin., 12: 99-111.

Da Silva, W.M., Roche, K.F., De Vicente, F.S. \& A.A. Delben. 2009. First Record of the peritrich Trichodina diaptomi Basson and Van As, 1991 (Protozoa: Ciliophora) on a

Received: March 2011

Accepted: April 2011
South American Calanoid Notodiaptomus deitersi (Poppe, 1890) (Crustacea: Copepoda). J. Eukaryot. Microbiol., 56: 385.

Fernández-Leborans, G. \& M.L. Tato-Porto. 2000. A review of the species of protozoan epibionts on crustaceans. I. Peritrich ciliates. Crustaceana, 73(6): 643-683.

Foissner, W., Berger, H. \& J Schaumburg. 1999. Identification and ecology of limnetic plankton ciliates. Bavarian State Office for Water Management, Munich: 793 pp.

Green, J.D. \& R.J. Shiel. 2000. Mobiline peritrich riders on Australian calanoid copepods. Hydrobiologia, 437: 203212.

Martins, M.L., Marchiori, N., Nunes, G. \& M.P. Rodrigues. 2010. First record of Trichodina heterodentata (Ciliophora: Trichodinidae) from channel catfish, Ictalurus punctatus cultivated in Brazil. Braz. J. Biol., 70: 637-644.

Mitra, A.K. \& P.K. Bandyopadhyay. 2005. First records of Trichodina japonica Imai, Miyazaki et Nomura 1991 and Trichodina mutabilis Kazubski et Migala 1968 (Ciliophora, Trichodinidae) from Indian fishes. Protistology, 4(2): 121-127.

Suárez-Morales, E. \& J.W. Reid. 1998. An updated list of the free-living freshwater copepods (Crustacea) of Mexico. Southwest. Nat., 43(2): 256-265.

Van As, J.G. \& L. Basson. 1989. A further contribution to the taxonomy of the Trichodinidae (Ciliophora: Peritrichia) and a review of the taxonomic status of some fish ectoparasitic trichodinids. Syst. Parasitol., 14: 157-179.

Xu, Z. \& C. W. Burns. 1991. Effects of the epizoic ciliate, Epistylis daphniae on growth, reproduction and mortality of Boeckella triarticulata (Thomson) (Copepoda: Calanoida). Hydrobiologia, 209: 183-189.

Xu, K. \& W. Song. 2008. Two trichodinid ectoparasites from marine molluscs in the Yellow Sea, off China, with the description of Trichodina caecellae n. sp. (Protozoa: Ciliophora: Peritrichia). Syst. Parasitol., 69: 1-11. 